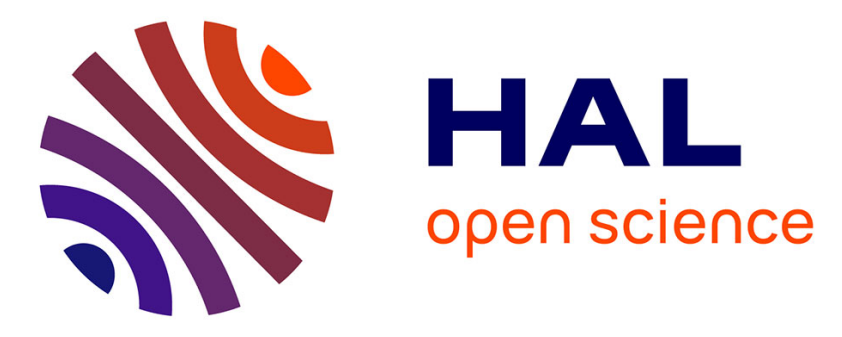

\title{
Improved detection specificity for plasma proteins by targeting cysteine-containing peptides with photo-SRM
}

Quentin Enjalbert, Marion Girod, Romain Simon, Jéremy Jeudy, Fabien

Chirot, Arnaud Salvador, Rodolphe Antoine, Philippe Dugourd, Jérôme Lemoine

\section{To cite this version:}

Quentin Enjalbert, Marion Girod, Romain Simon, Jéremy Jeudy, Fabien Chirot, et al.. Improved detection specificity for plasma proteins by targeting cysteine-containing peptides with photo-SRM. Analytical and Bioanalytical Chemistry, 2013, 405 (7), pp.2321-2331. 10.1007/s00216-012-6603-5. hal-00875276

\section{HAL Id: hal-00875276 https://hal.science/hal-00875276}

Submitted on 4 Sep 2020

HAL is a multi-disciplinary open access archive for the deposit and dissemination of scientific research documents, whether they are published or not. The documents may come from teaching and research institutions in France or abroad, or from public or private research centers.
L'archive ouverte pluridisciplinaire $\mathbf{H A L}$, est destinée au dépôt et à la diffusion de documents scientifiques de niveau recherche, publiés ou non, émanant des établissements d'enseignement et de recherche français ou étrangers, des laboratoires publics ou privés. 


\title{
Improved detection specificity of plasma proteins by targeting cysteine-containing peptides with photo-SRM
}

Quentin Enjalbert ${ }^{a, b, c}$, Marion Girod ${ }^{a, c}$, Romain Simon ${ }^{a, c}$, Jérémy Jeudy ${ }^{a, c}$, Fabien Chirot ${ }^{a, c}$, Arnaud Salvador ${ }^{a, c}$, Rodolphe Antoine ${ }^{a, b}$, Philippe Dugourd ${ }^{a, b^{*}}$, Jérôme Lemoine ${ }^{a, c^{*}}$.

\author{
${ }^{a}$ Université Lyon, F-69622, Lyon, France ; \\ ${ }^{\mathrm{b}}$ CNRS et Université Lyon 1, UMR5306, ILM. \\ c CNRS et Université Lyon 1 UMR 5280, ISA
}

${ }^{4}$ To whom correspondence should be addressed:

Jérôme Lemoine: jerome.lemoine@univ-lyon1.fr 


\begin{abstract}
Targeted mass spectrometry using Selected Reaction Monitoring (SRM) mode has emerged as an alternative technology to immuno-assay for protein quantification owing to faster development time and high multiplexing capability. However, SRM strategy faces the high complexity of peptide mixtures after trypsin digestion of whole plasma or cellular proteome that irremediably causes most of the time contaminations by interfering compounds in the monitored transition channels. This event becomes more and more acute as the targeted protein is present at a low concentration. In the present work, the merit of laser induced photo-dissociation in the visible range at $473 \mathrm{~nm}$ implemented in an hybrid quadrupole linear ion trap mass spectrometer (photo-SRM) was evaluated towards the detection specificity of cysteine-containing peptides of a panel of plasma proteins after tagging with a DABCYL chromophore. Compared to conventional SRM, photo-SRM chromatograms depict improved detection specificity for most of monitored peptides. The comparison of the signals obtained for best proteotypic peptides in SRM mode and those recorded by photo-SRM on cysteine-containing peptides for the same proteins shows either increased (up to 10 fold) or similar signal with photo-SRM detection. Finally, photo-SRM demonstrates extended response linearity across a calibration curve obtained by diluting human plasma in rat plasma, down to the lowest concentrations. Hence, photo-SRM may advantageously complement conventional SRM in assaying proteins in complex biological matrices.
\end{abstract}

\title{
Keywords
}

Photo-SRM, cysteine-containing peptides quantification, chromophore derivatization, plasma proteins.

\section{Introduction}

Accurate quantification of proteins and peptides in complex matrices such as plasma, serum or urine is currently a key issue, particularly with the growing interest for clinical evaluation of candidate biomarkers identified during the proteomic discovery phases [1]. Until recently, this critical evaluation step relied primarily on immunoassays, such as ELISA, thanks to their specificity toward the target analyte and the sensitivity (pg of proteins per $\mathrm{mL}$ of plasma). However, the development of a new immunoassay is very expensive because it is often long and tightly dependent of specific antibody discovery [2,3]. Mass spectrometry has recently emerged 
as an alternative method to immunoassay for quantitative proteomics approaches. Targeted quantification carried out with triple quadrupole instrument relies on the monitoring in the so-called Selected Reaction Monitoring mode (SRM) of surrogate peptides following trypsin digestion of the protein pool [4]. The value of SRM-based absolute quantification has been now widely illustrated for numerous relatively abundant plasma proteins or few weakly concentrated biomarkers and good correlations with the referent immunoassays have been demonstrated [5-10]. It remains that, unless extensive depletion of the more abundant protein, peptide fractionation or immuno enrichment [11,12], the current sensitivity of SRM does not provide the access to the lowest limit of quantification (LOQ) required for the reliable quantification of most clinically relevant biomarkers (pg of proteins per $\mathrm{mL}$ ). This limitation is the consequence of the huge dynamic range of protein concentrations in biological extracts spanning 12 orders of magnitude in human plasma while only 4 to 6 orders are measurable in a whole sample. The second reason arises from the great complexity of a non-fractionated tryptic digest where the likelihood of co-eluted interfering compounds sharing similar SRM transitions with the targeted peptide is high.

Recently, instrumental and methodological developments brought partial responses to improve the monitoring of peptides in non-fractionated proteomic extracts. For instance, the ion funnel technology combined with a multi-capillary inlet enables in average a ten-fold increase of SRM peak intensities [13]. In an attempt to improve the detection specificity, we recently documented the value of a new technique called MRM-cubed $\left(\mathrm{MRM}^{3}\right)[14,15]$. By adding an additional $\mathrm{MS}^{3}$ filtering stage, an outstanding low LOQ of about $5 \mathrm{ng} / \mathrm{mL}$ was demonstrated for the Prostate Specific Antigen model of biomarker in clinical samples of plasma without any extensive fractionation. An alternative to overcome the hurdle of tryptic digest complexity and dynamic range would consist in targeting only a limited subset of the original peptide mixture, by considering only the rare cysteine-containing peptides. Indeed, cysteine (Cys, C) is present in almost all human proteins $(89.3 \%$ harbor at least one), but only $17.2 \%$ of tryptic peptides contain one or more cysteine residues [16]. Beside, Cysteine is also among the most reactive amino acids through the strong reactivity of the side-chain thiol group towards oxidizing or alkylating reagents. This weak abundance has been judiciously exploited to help for proteomic discovery of differentially expressed and/or minor proteins [17]. The probably best accomplished well-known isotope coded affinity tag reagent (ICAT) [18] bears for instance a thiol reactive group and biotin to facilitate selective enrichment on avidin beads. 
Natural or induced optical properties of biological molecules like fluorescence are also interesting filters to extract specific signals from the bulk compounds present in the surrounding cellular matrix [19].

In the field of mass spectrometry, significant contributions by numerous groups have highlighted for years the value of photon absorption in the UV or IR wavelength ranges to induce dissociation of peptides and proteins [20-24], such as the use of ultraviolet photo-dissociation at $266 \mathrm{~nm}$ to selectively cleave disulfide bonds in the gas phase [25], sugars [26-28], oligonucleotides [29-33] or small organic compounds [34]. Specific optical properties can be induced in proteins or peptides following chromophore-derivatization [35,36]. In a preliminary work, we have demonstrated that a new method called photo-SRM could be a valuable option to improve the detection specificity in SRM mode [37]. Following peptide derivatization with a chromophore and substituting the conventional collision-induced dissociation (CID) with laser-induced dissociation (LID), the limit of detection of chromophore-tagged oxytocin peptide spiked in a whole trypsin digest of human plasma was extended to lower concentration range. Similarly, the group of Brodbelt described favoured cleavages induced by $10.6 \mu \mathrm{m}$ photons of phosphorylated species that help to discriminate between phosphorylated and nonphosphorylated peptides [38] or lipid A structures [39].

In the present work, we evaluate the merit of photo-SRM implemented in a hybrid quadrupole linear ion trap instrument towards proteins detection specificity. We report the detection and quantification of 6 proteins of high to medium abundances. For about half of the proteins, the signal intensity provided by photo-SRM targeting cysteine-containing peptides tagged with a dabcyl group is similar or increased when compared to the signal measured by CID-SRM tracking the best proteotypic peptide. Hence, the ease of photo-SRM implementation in a commercial triple quadrupole instrument makes this technique complementary for the challenges posed by multiplexed quantification of proteins in biological fluids or any other compounds with specific absorption properties. 


\section{Material and methods}

Chemicals and reagents.

Acetonitrile $(\mathrm{ACN})$, methanol $(\mathrm{MeOH})$ and water (LC-MS grade) were obtained from Fisher Scientific (Strasbourg, France). Dithiothreitol (DTT), iodoacetamide (IAM), formic acid (FA) (LC-MS grade), trypsin (type IX-S from Porcine Pancreas), ammonium bicarbonate (AMBIC), tris(2-carboxyethyl)phosphine (TCEP), ammonium acetate (AA) were purchased from Sigma-Aldrich (St Quentin-Fallavier, France). DABCYL C2 maleimide was purchased from AnaSpec (Fremont, CA). Human serum was obtained from Etablissement Français du Sang. Rat plasma was obtained from Charles River Laboratories (L'Arbresle, France). Prostate Specific Antigen (PSA) proteotypic peptide (IVGGWECEK) was synthesized by Millegen (Labège, France).

Instrumentation.

SRM and Photo-SRM analyses were performed on an 4000 QTRAP® mass spectrometer (AB Sciex, Foster City, CA, USA) equipped with a Turbo $\mathrm{V}^{\mathrm{TM}}$ ion source coupled to an Agilent 1290 series high pressure liquid chromatography (Agilent technologies, Waldbronn, Germany). A schematic of the photo-SRM set-up is given in Scheme S1 in Online Resource. A quartz window was fitted on the rear of the MS instrument chamber to allow the introduction of a laser beam. The laser is a $473 \mathrm{~nm}$ continuous wavelength laser (cw) (ACAL BFI, Evry, France). The output power of the laser is tunable from 0 to $500 \mathrm{~mW}$ and its beam diameter is $1.5 \mathrm{~mm}$ (divergence $1 \mathrm{mrad}$ ). The laser beam passes through one diaphragm and is injected in the triple quadrupole instrument using two mirrors. To avoid fragmentation in Q1 and Q3, the laser beam is slightly off-axis $\left(\sim 0.2^{\circ}\right)$ as explained in the proof of concept article [37]. For photo-SRM analyses, the continuous laser is permanently turned on.

MS/MS experiments in data dependent scan were done using a 5500 QTRAP ${ }^{\circ}$ mass spectrometer $(A B$ Sciex, Foster City, CA, USA) equipped with a Turbo $\mathrm{V}^{\mathrm{TM}}$ ion source coupled to an Agilent 1290 series high pressure liquid chromatography (Agilent technologies, Waldbronn, Germany).

HPLC separation. 
For chromophore-derivatization-condition experiments in photo-SRM and SRM, the HPLC separation was carried out on a XBridge $\mathrm{C}_{8}$ column $(100 \times 2.1 \mathrm{~mm}, 3.5 \mu \mathrm{m})$ from Waters. The HPLC mobile phase consisted of water containing formic acid $0.1 \%(\mathrm{v} / \mathrm{v})$ as eluent $\mathrm{A}$ and $\mathrm{ACN}$ containing formic acid $0.1 \%(\mathrm{v} / \mathrm{v})$ as eluent $\mathrm{B}$. Elution was performed at a flow rate of $300 \mu \mathrm{L} / \mathrm{min}$ with an analysis time of $65 \mathrm{~min}$. The elution sequence included a plateau with $87 \%$ of eluent A for 2 min followed by a linear gradient from $87 \%$ to $62 \%$ over 45 min, then a plateau at $0 \%$ of eluent $\mathrm{A}$ for $8 \mathrm{~min}$. The gradient was returned to the initial conditions and held there for $10 \mathrm{~min}$. The injection volume was $20 \mu \mathrm{L}$ in order to inject $2 \mu \mathrm{L}$ of serum equivalent. For MS/MS experiments the same HPLC conditions as photo-SRM were applied.

For SRM analyses of common proteotypic peptides, the HPLC separation is described in the Electronic Supplementary Material (ESM).

Mass Spectrometry Operating Conditions.

For photo-SRM and SRM experiments on the cysteine-derivatized peptides, the following conditions were found to be a compromise in order to detect the largest number of tagged peptides from human serum. Ionization was achieved using electrospray in the positive ionization mode with an ion spray voltage of $5500 \mathrm{~V}$. The curtain gas flow (nitrogen), the ion source gas 1 and 2 (air) were respectively set at 10, 30 and 20 units. The Turbo ion spray source was operating at $250^{\circ} \mathrm{C}$. Q1 and Q3 quadrupole resolution was adjusted $\sim 1.1 \pm 0.1$ amu. For CID experiments the collision energy was set to $40 \mathrm{eV}$ for doubly charged ions and $20 \mathrm{eV}$ for triply charged ions (shown in Table 1). For LID, the collision energy was reduced to $5 \mathrm{eV}$ (to avoid CID). The laser power was adjusted at $500 \mathrm{~mW}$. For discovery analyses, 120 SRM transitions (couple precursor ion/product ion) were simultaneously followed in SRM and photo-SRM experiments with a dwell time of $20 \mathrm{~ms}$. For final analyses, 12 SRM transitions were followed in SRM and photo-SRM experiments with a dwell time of $50 \mathrm{~ms}$.

For MS/MS experiments in data dependent scan, ionization was achieved using electrospray in the positive ionization mode using an ion spray voltage of $5500 \mathrm{~V}$. The curtain gas flow (nitrogen), the ion source gas 1 and 2 (air) were respectively set at 50,50 and 40 units. The Turbo ion spray source was operating at $250^{\circ} \mathrm{C}$. Q1 and Q3 quadrupole resolution was adjusted $0.7 \pm 0.1$ amu. Collision energy was set to $40 \mathrm{eV}$ for doubly charged ions and $20 \mathrm{eV}$ for triply charged ions.

Photo-SRM has been compared to classical SRM analyses on common proteotypic peptides. For these experiments, mass spectrometry operating conditions are described in the ESM. 
Sample Preparations.

For experimental gas-phase photo-fragmentation spectrum and sample stability experiments, PSA proteotypic peptide was derivatized with a 3 -fold molar excess solution of TCEP $(0.1 \mathrm{mg} / \mathrm{mL}$ in a $60 \mathrm{mM}$ AA solution, $\mathrm{pH}=$ 8-8.5) and a 5-fold molar excess of DABCYL C2 maleimide in $\mathrm{MeOH}(1.33 \mu \mathrm{g} / \mathrm{mL}$ in $\mathrm{MeOH})$. The mixture was stirred in the sonic bath then stored in the dark for $4 \mathrm{~h}$ at room temperature.

For SRM analyses of common proteotypic peptides, sample preparation is described in Online Resource.

For SRM and photo-SRM analyses, cysteine-containing proteins were derivatized with DABCYL C2 maleimide (structure shown in Fig. S1a in ESM). The whole human serum derivatization was realized as followed. $10 \mu \mathrm{L}$ of human serum was dissolved in $3000 \mu \mathrm{L}$ of a 3 -fold molar excess solution of TCEP $(0.1$ $\mathrm{mg} / \mathrm{mL}$ in a $60 \mathrm{mM}$ AA solution). Then, $3000 \mu \mathrm{L}$ of a 5 -fold molar excess of DABCYL C2 maleimide in $\mathrm{MeOH}(1.33 \mu \mathrm{g} / \mathrm{mL}$ in $\mathrm{MeOH})$ was added. The mixture was stirred in the sonic bath then stored in the dark for $4 \mathrm{~h}$ at room temperature. The samples were diluted with $3000 \mu \mathrm{L}$ of a $60 \mathrm{mM}$ AA solution prior to overnight digestion at $37^{\circ} \mathrm{C}$ with trypsin using a 1:30 (w/w) enzyme to substrate ratio. Digestion was stopped by addition of formic acid to a final concentration of $0.5 \%$. All samples were desalted and concentrated using Oasis ${ }^{\mathrm{TM}} \mathrm{HLB}$ $3 \mathrm{cc}(60 \mathrm{mg})$ reversed phase cartridges (Waters, Milford, MA, USA). Before loading the tryptic digest onto the Oasis cartridges, all cartridges were conditioned with $1 \mathrm{~mL}$ of $\mathrm{MeOH}$ and then $1 \mathrm{~mL}$ of water containing $0.5 \%$ FA. After the loading, all cartridges were washed with $1 \mathrm{~mL}$ of $\mathrm{MeOH} /$ water $(5 / 95, \mathrm{v} / \mathrm{v})$ containing $0.5 \% \mathrm{FA}$ and eluted with $2 \mathrm{~mL}$ of ACN containing $0.5 \%$ FA. All samples were evaporated to dryness and resuspended in 100 $\mu \mathrm{L}$ of water $/ \mathrm{MeOH}(2: 1, \mathrm{v} / \mathrm{v})$ containing $0.5 \% \mathrm{FA}$. All solutions were stored at $-18^{\circ} \mathrm{C}$ prior to use.

Standard samples for calibration curves were prepared by diluting human serum into rat plasma prior to the whole sample preparation. The human serum volume ratios were $0,0.01,0.02,0.1,0.20,0.5$ and 1.0. Each standard sample was separately derivatized, digested with trypsin and desalted as described above. Triplicates of each standard were realized. C4b Binding Protein Alpha Chain calibration curves (SRM and photo-SRM) were obtained by diluting human serum into rat plasma. The initial C4b Binding Protein Alpha Chain concentration was estimated to be $337.5 \mu \mathrm{g}$ of protein per $\mathrm{mL}$ in human serum [40]. 


\section{Results and discussion}

The aim of the present work was to assess the value of photo-SRM, for the targeted quantification of proteins in plasma by tracking cysteine-containing peptides. In the experimental set-up, a continuous $473 \mathrm{~nm}$ laser beam was focused slightly off-axis in the collision cell of a commercial hybrid quadrupole linear ion trap mass spectrometer to allow analyses either in collision-induced (laser turned off) or laser-induced dissociation mode (laser turned on). The choice to irradiate in the visible range was governed by the non-absorbing property of the vast majority of natural molecules around $473 \mathrm{~nm}$, which is the case for peptides and proteins. The LID mass spectrum of the unmodified PSA proteotypic peptide IVGGWECEK obtained following laser irradiation at $473 \mathrm{~nm}$ (see ESM, Fig. S1) does not show any product ion, which is relevant with the non-absorbing properties of proteins and peptides in the visible range. However, specific photo-dissociation is expected from the same peptide after derivatization with an adequate chromophore. As mentioned in the introduction section, the tagging of cysteine thiol group constitutes a key advantage in the quest for specificity and sensitivity considering that cysteine is a rare amino acid and that the thiol reactivity towards the maleimide functionalized chromophore is usually stoichiometric. Numerous chromophores are commercially available with a thiol-reactive group but a very few have quenching property. Among them, DABCYL C2-maleimide has a high photo-dissociation yield between 465 and $540 \mathrm{~nm}$ as shown by the optical spectrum of tagged PSA proteotypic peptide IVGGWECEK recorded on a linear ion trap coupled with an OPO laser $[20,28]$ (Fig. S2a in ESM). When no product ions can be observed with the unmodified peptide after laser irradiation at $473 \mathrm{~nm}$ (Fig. S1 in ESM), several product ions are detected with the tagged peptide (Fig. S2b in ESM). Similar product ions are obtained with LID and CID fragmentation (Fig. S2c in ESM), and only ratios between fragments show some differences, thus there is no specific fragment obtained with either one or the other method. The most intense product ions derive from internal dissociation of the chromophore providing two complementary ions at $m / z, 252$ and $[\mathrm{M}+\mathrm{H}-252]^{+}($Fig. S2d in ESM).

The completion of the chromophore-derivatization has been verified by analyzing a sample of PSA proteotypic peptide (Fig. S3 in ESM). After addition of the chromophore, any signal for the 3 SRM transitions (couple precursor ion/product ion) tracking the unmodified peptide (510.5/213.2, 510.5/693.3 and 510.5/750.3) could be observed while the 2 SRM transitions tracking the tagged peptide were detected providing that the tagging reaction is complete in these conditions. In order to assess the chemical stability of tagged IVGGWECEK peptide towards normal room conditions, a potential source of imprecision in case of spontaneous degradation, the intensity of SRM signals 707/252 and 707/1161 were monitored for three storage 
conditions, i.e. room light/room temperature, room light $/ 4^{\circ} \mathrm{C}$ regulated autosampler, darkness $/ 4^{\circ} \mathrm{C}$ regulated autosampler. Fig. S4 in ESM shows the time course of the cysteine-tagged peptide signal stability sampled every 30 minutes over a $12 \mathrm{~h}$ period. After $6 \mathrm{~h}$, the SRM signals slightly decrease by $5 \%$ and by $15 \%$ after $12 \mathrm{~h}$, whatever the storage conditions. This signal loss has been thus considered negligible for the following experiments in the present study. Nevertheless, the imprecision arising from this chemical degradation might alternatively be corrected for future assays by spiking an internal heavy peptide standard.

Relative performance of photo-SRM versus SRM.

We first extracted all tryptic peptides containing between 5 and 15 amino-acids residues and a single cysteine from a list of 30 concentrated human plasma proteins spanning a dynamic range of 4 orders of magnitude with the open source Skyline software (http://proteome.gs.washington.edu/software/skyline) [40-42]. These features filtered a set of 70 peptides. By extrapolating the above fragmentation pattern of tagged PSA peptide, a list of theoretical transitions was build considering doubly or triply protonated precursor ions for each peptide, the chromophore fragment at $\mathrm{m} / \mathrm{z} 252$ and its complementary charge reduced product ion retaining the peptide moiety, see Table S1 in Online Resource. All putative transitions were next monitored by photo-SRM towards a whole trypsin digest of human plasma sample $(10 \mu \mathrm{L})$ derivatized with DABCYL C2-maleimide. The derivatization was performed at the protein level in order to cleave disulfide bonds and allow a complete tryptic digestion. The analysis leads to the detection of 23 peaks showing significant signals within the two targeted transition channels. This low number of detected peptides could be explained by the low ionization yield of these peptides and the matrix complexity. The Fig. 1 shows the superimposed reconstructed ion chromatograms of most intense peaks recorded either in photo-SRM (Fig. 1a) or SRM modes (Fig. 1b) for the same derivatized sample. Compared to SRM, fewer signals are observed in photo-SRM, especially in the first half of the chromatogram where non-derivatized (more hydrophilic) peptides are expected to elute. Note that owing to a marked increase in peptide hydrophobicity after chromophore tagging, we moved from a classical $\mathrm{C}_{18}$ reversed phase column to a $\mathrm{C}_{8}$ reversed phase in order to keep enough peak capacity during the chromatographic separation. In turn, a large fraction of non-derivatized peptides are early eluted even at the weakest percentage of organic solvent, which advantageously contributes to minor both matrix effect and probability of co-eluting interferences. This first result clearly indicates that tracking cysteine-containing peptides derivatized with the DABCYL chromophore is univocally more specific when applying photo-SRM instead of SRM, as expected. 
In order to validate the peptide identities, tandem CID mass spectra were recorded in data dependent scan triggered tandem mass spectrometry on all putative transitions. This experiment has been carried out on a more recent unmodified hybrid quadrupole linear ion trap mass spectrometer (5500 QTRAP®) mass spectrometer) owing to its increased sensitivity in acquiring product ion spectra. Among the multiplicity of detected peaks, 7 targeted peptide sequences were confidently attributed to proteins of high to medium abundances i.e. albumin, afamin, $\mathrm{C} 4 \mathrm{~b}$ binding protein alpha chain, complement $\mathrm{C} 3$, isoform 1 of gelsolin, beta chain of haptoglobin and plasminogen. Based on the values reported by Anderson et al. [40], the concentrations of these proteins range from $150 \mu \mathrm{g}$ of protein per $\mathrm{mL}$ for the lowest concentrated afamin protein to $50 \mathrm{mg}$ of protein per $\mathrm{mL}$ for albumin. CID MS/MS spectra of 4 from the 7 corresponding proteotypic cysteine-containing peptides are shown in Figures 2a-d and correspond to the dissociation spectra of triply charged ions (see Fig. S5 for the 3 other CID MS/MS spectra). Unidentified ions could probably come from co-eluted compound with the same precursor ion. Though the chromophore-tagged peptides were also detected as doubly charged species in SRM-triggered MS/MS experiments, $[\mathrm{M}+3 \mathrm{H}]^{3+}$ were mostly detected as the predominant pseudo-molecular ions. This feature likely results from the high proton affinity of the amine group carried by the DABCYL C2maleimide quencher (Fig. S2) that introduces an additional favoured protonation site. Furthermore, the triply charged ions showed a better fragmentation efficiency and provide more informative fragmentation patterns than their doubly charged homologues and were consequently only considered for the succeeding experiments. Beside the systematic detection of a fragment ion at $\mathrm{m} / \mathrm{z} 252$ arising from the dissociation within the chromophore group, peptide sequences were established according to $b_{n}$ and $y_{n}$ fragment ions (y ions are much more intense than $\mathrm{b}$ ions). These backbone fragment ions retaining the chromophore group have been chosen to reconstruct the ion chromatograms owing to increase specificity with regard to the non-specific product ion at $m / z 252$ available with every tagged peptide. Note that the fragmentation parameters were not optimized to record optimal SRM signals since we did not have an access to synthetic peptides. Hence, an average collision energy of $20 \mathrm{eV}$ has been chosen for all triply charged peptides while $40 \mathrm{eV}$ has been chosen for doubly charged peptides for subsequent monitoring in SRM on the dedicated instrument. On the other side, we cannot neither optimize the laser power for each peptide so a value of $500 \mathrm{~mW}$ has been chosen for doubly and triply charged peptides.

The comparison of the relative merits of photo-SRM and CID-SRM detection selectivity for cysteinecontaining peptides has been made for these 7 proteins. Figure 2e-h shows, as an example, superimposed extracted ion chromatograms of the most specific transition defined for afamin $(2 a)$, C4b binding protein alpha 
chain (2b), complement C3 (2c) and gelsolin (2d) proteins by photo-SRM (black line) or SRM (red line) monitoring. Except for $\mathrm{C} 4 \mathrm{~b}$ binding protein alpha chain, all photo-SRM chromatograms (black) exhibit less interfering compounds than SRM ones (red). This is especially spectacular in the case of cysteine-tagged peptide of afamin. For this latter, it is clearly detected at $\operatorname{tr}=25.04 \mathrm{~min}$ in the human plasma sample (mean endogenous concentration comprises between 75 and $250 \mu \mathrm{g} / \mathrm{mL}$ ) using photo-SRM, whilst only interfering ions are detected in SRM mode (Fig. 2e). Together, these chromatograms unambiguously highlight the higher specificity of LID mode in detecting cysteine-containing peptides grafted with a chromophore group. Having demonstrated the superior detection specificity of photo-SRM, we next wanted to compare the overall sensitivity of photo-SRM tracking cysteine peptides with regard to the sensitivity of SRM monitoring the best proteotypic peptides for the same set of proteins. From a list of SRM transitions generated by MRM pilot software tool and consistent with the literature [43], the most sensitive transition for each peptide was monitored on the same instrument used for photo-SRM for the 7 targeted proteins. Figure S6 in Online Resource shows the extracted ion chromatograms of the most intense SRM transitions obtained for each proteotypic peptide. None of the most sensitive peptides followed in SRM contain a cysteine residue thus they all differ from the cysteine-tagged peptides monitored in photo-SRM. The spectral counts of best proteotypic peptides monitored in SRM and cysteine-containing peptides tracked by photo-SRM for the 7 targeted proteins starting from $2 \mu \mathrm{L}$ of serum are reported in Table 1 . Taken as a whole, the area and the height of the different signals are in a close range of value in photo-SRM and in SRM. Nonetheless, while we can noticed a slight decrease of sensitivity for afamin, albumin, gelsolin and plasminogen moving from SRM to photo-SRM, signals are increased in turn for C4b binding protein alpha chain, haptoglobin and more especially for complement $\mathrm{C} 3$ showing a nearly 10 fold signal enhancement in photo-SRM mode. The retention times of tagged-peptides are much greater than the non-modified ones. Therefore, they elute in a portion of the chromatogram where the ratio of water/organic eluent is lower. Greater percentages of organic solvent lead to higher ionization efficiencies and result in greater signal. Thus, the improvement in sensitivity obtained by the photo-SRM analysis of the tagged-peptides against SRM analysis of the best proteotypic peptides could be attributed to the whole method (sample preparation, liquid chromatography and laser-fragmentation) and not only to the laser-fragmentation.

These results indicate that quantification of some cysteine-containing proteins could be achieved by photo-SRM as a comparable or even better level to classical SRM for some peptides. In other words, we cannot claim that photo-SRM is a universal substitute to conventional SRM but it should be considered in the future as a 
powerful alternative or more sensitive strategy for the quantification of some candidates and should be thus evaluated during the assay development.

Response linearity.

In order to assess the linearity of the complete sample workflow including the chromophore derivatization step we diluted human serum into rat plasma prior to sample preparation. Amongst 7 validated peptides only 6 were finally monitored in the dilution experiments due to the presence of the same endogenous cysteine-containing proteotypic peptide in rat serum coming from haptoglobin. From mean concentration values for the pure human serum, six different dilutions of human serum into rat plasma, over 2 decades, were prepared and analyzed in SRM and photo-SRM modes. The specificity of all SRM transitions was first assessed for both activation modes across the analysis of blank rat plasma hydrolysates i.e. not spiked with human serum). Figure 3 shows the ion chromatograms reconstructed on the most intense transition (732/1212) monitoring the cysteine-tagged peptide of the $\mathrm{C} 4 \mathrm{~b}$ binding protein alpha chain recorded in photo-SRM (Fig. 3a) and CID-SRM (Fig. 3c). The redundancy within the monitored transition channel displayed by the chromatograms between 25 and 30 min corresponds to interfering endogenous rat serum compounds. Using CID-SRM, a weak but noticeable interference is detected at the elution time expected (indicated by an arrow) for the targeted peptide tagged with DABCYL C2-maleimide quencher (insert in Fig. 3c). In contrast, no interference is detected at this retention time moving to photo-SRM mode, which features a higher specificity of $473 \mathrm{~nm}$ laser excitation process with regard with CID mode.

Figures $3 b$ and $3 c$ show the extracted ion chromatograms recorded in photo-SRM and CID-SRM of the same SRM transition for the lowest detected concentration of the calibration curve, i.e. $6.75 \mu \mathrm{g} / \mathrm{mL}$. First, as foreseen by the analysis of the blank rat serum sample, the occurrence of a co-eluted interference at $26.4 \mathrm{~min}$ on the CID-SRM chromatogram precludes the detection of the targeted peptide at this lowest concentration range. This is illustrated by the Y-intercept value of the chromophore tagged peptide SRM calibration curve, which is consistent with a systematic peak contamination below $67.5 \mu \mathrm{g} / \mathrm{mL}$ (insert in Fig. 3e). In contrast, the zero- noise baseline level of blank rat serum monitored by photo-SRM allows the detection of the targeted peptide even at this lowest concentration, hence extends the response linearity all over the investigated range of concentrations $\left(r^{2}=0.999\right)$ i.e. between 6.75 and $337.5 \mu \mathrm{g} / \mathrm{mL}$. 
By analyzing the results from a triplicate of the full experimental sample workflow (i.e. chromophore tagging, sample digestion, SPE), accuracy for measuring the ratio between nominal and back-calculated concentrations was in the range 80-115 over all the proteins, except for one concentration point (Table 2). Similarly, imprecision values expressed by the coefficient of variation (CV) were nearly all better than $20 \%$. This shows that the robustness and the repeatability for the whole analytical process can be validated. These statistics are somewhat acceptable in a first attempt and in line with previous reports [44-47] if one considers that we did not used in the present study heavy internal standard usually employed to adjust for instance variation in the trypsin digestion step of different matrix effect from one sample to another one.

\section{Conclusions}

In the present work, we explored the potential interest of photo-SRM for the targeted detection of cysteinecontaining peptides in a whole human plasma digest after tagging with a DABCYL group absorbing at the laser wavelength i.e. $473 \mathrm{~nm}$. The conferred selective optical absorption property allows the introduction of a new specificity at the dissociation step by substituting the conventional collisional process by laser-induced dissociation mode in SRM. This increased specificity has been here clearly demonstrated by the dramatic decrease of interfering peaks originating from isobaric peptides and product ions. As a consequence, linearity of photo-SRM signal was conserved even at the lowest concentrations of human $\mathrm{C} 4 \mathrm{~b}$ binding protein alpha chain when human plasma was diluted in rat plasma. Across a panel of 7 human plasma proteins, the overall sensitivity of photo-SRM monitoring cysteine-containing peptides compared well with conventional SRM when tracking the best responding proteotypic peptides and was markedly improved for one of them. Hence, photo-SRM appears not as an alternative to replace conventional SRM but more like a powerful complement that in many instances equals or may improve the limit of quantitation of protein targets.

\section{Acknowledgment}

The authors would like to acknowledge the French Agence National de la Recherche for the funding of photoSRM project (ANR-11-BSV5-003-01). 


\section{References}

1. Anderson NL, Anderson NG (2002) The human plasma proteome - History, character, and diagnostic prospects. Mol Cell Proteomics 1 (11):845-867

2. Keshishian H, Addona T, Burgess M, Kuhn E, Carr SA (2007) Quantitative, multiplexed assays for low abundance proteins in plasma by targeted mass spectrometry and stable isotope dilution. Mol Cell Proteomics 6 (12):2212-2229

3. Anderson L, Hunter CL (2006) Quantitative mass spectrometric multiple reaction monitoring assays for major plasma proteins. Mol Cell Proteomics 5 (4):573-588

4. Elliott MH, Smith DS, Parker CE, Borchers C (2009) Current trends in quantitative proteomics. J Mass Spectrom 44 (12):1637-1660

5. Barnidge DR, Goodmanson MK, Klee GG, Muddiman DC (2004) Absolute quantification of the model biomarker prostate-specific antigen in serum by LC-MS/MS using protein cleavage and isotope dilution mass spectrometry. J Proteome Res 3 (3):644-652

6. Fortin T, Salvador A, Charrier JP, Lenz C, Lacoux X, Morla A, Choquet-Kastylevsky G, Lemoine J (2009) Clinical Quantitation of Prostate-specific Antigen Biomarker in the Low Nanogram/Milliliter Range by Conventional Bore Liquid Chromatography-Tandem Mass Spectrometry (Multiple Reaction Monitoring) Coupling and Correlation with ELISA Tests. Mol Cell Proteomics 8 (5):1006-1015

7. Hoofnagle AN, Becker JO, Wener MH, Heinecke JW (2008) Quantification of Thyroglobulin, a Low-Abundance Serum Protein, by Immunoaffinity Peptide Enrichment and Tandem Mass Spectrometry. Clin Chem 54 (11):1796-1804

8. Domon B, Aebersold R (2010) Options and considerations when selecting a quantitative proteomics strategy. Nat Biotechnol 28 (7):710-721

9. Huettenhain R, Malmstroem J, Picotti P, Aebersold R (2009) Perspectives of targeted mass spectrometry for protein biomarker verification. Curr Opin Chem Biol 13 (5-6):518-525

10. Lin S, Shaler TA, Becker CH (2006) Quantification of intermediate-abundance proteins in serum by multiple reaction monitoring mass spectrometry in a single-quadrupole ion trap. Anal Chem 78 (16):5762-5767

11. Callipo L, Caruso G, Foglia P, Gubbiotti R, Samperi R, Lagana A (2010) Immunoprecipitation on magnetic beads and liquid chromatography-tandem mass spectrometry for carbonic anhydrase II quantification in human serum. Anal Biochem 400 (2):195-202

12. Winther B, Nordlund M, Paus E, Reubsaet L, Halvorsen TG (2009) Immuno-capture as ultimate sample cleanup in LC-MS/MS determination of the early stage biomarker ProGRP. J Sep Sci 32 (17):2937-2943

13. Hossain M, Kaleta DT, Robinson EW, Liu T, Zhao R, Page JS, Kelly RT, Moore RJ, Tang K, Camp DG, II, Qian W-J, Smith RD (2011) Enhanced Sensitivity for Selected Reaction Monitoring Mass Spectrometry-based Targeted Proteomics Using a Dual Stage Electrodynamic Ion Funnel Interface. Mol Cell Proteomics 10 (2)

14. Fortin T, Salvador A, Charrier JP, Lenz C, Bettsworth F, Lacoux X, Choquet-Kastylevsky G, Lemoine J (2009) Multiple Reaction Monitoring Cubed for Protein Quantification at the Low Nanogram/Milliliter Level in Nondepleted Human Serum. Anal Chem 81 (22):93439352

15. Lemoine J, Fortin T, Salvador A, Jaffuel A, Charrier J-P, Choquet-Kastylevsky G (2012) The current status of clinical proteomics and the use of MRM and MRM(3) for biomarker validation. Expert Rev Mol Diagn 12 (4):333-342 
16. Wang SH, Zhang X, Regnier FE (2002) Quantitative proteomics strategy involving the selection of peptides containing both cysteine and histidine from tryptic digests of cell lysates. J Chromatogr A 949 (1-2):153-162

17. Giron P, Dayon L, Sanchez J-C (2011) Cysteine Tagging for Ms-Based Proteomics. Mass Spectrom Rev 30 (3):366-395

18. Gygi SP, Rist B, Gerber SA, Turecek F, Gelb MH, Aebersold R (1999) Quantitative analysis of complex protein mixtures using isotope-coded affinity tags. Nat Biotechnol 17 (10):994-999

19. Hoffman RM (2005) The multiple uses of fluorescent proteins to visualize cancer in vivo. Nat Rev Cancer 5 (10):796-806

20. Larraillet V, Antoine R, Dugourd P, Lemoine J (2009) Activated-Electron Photodetachment Dissociation for the Structural Characterization of Protein Polyanions. Anal Chem 81 (20):8410-8416

21. Reilly JP (2009) Ultraviolet Photofragmentation of Biomolecular Ions. Mass Spectrom Rev 28 (3):425-447

22. Tecklenburg RE, Miller MN, Russell DH (1989) Laser Ion-Beam Photodissociation Studies of Model Amino-Acids and Peptides. J Am Chem Soc 111 (4):1161-1171

23. Williams ER, Furlong JJP, McLafferty FW (1990) Efficiency of Collisionally-Activated Dissociation and 193-Nm Photodissociation of Peptide Ions in Fourier-Transform MassSpectrometry. J Am Soc Mass Spectrom 1 (4):288-294

24. Ly T, Julian RR (2009) Ultraviolet Photodissociation: Developments towards Applications for Mass-Spectrometry-Based Proteomics. Angew Chem-Int Edit 48 (39):71307137

25. Agarwal A, Diedrich JK, Julian RR (2011) Direct Elucidation of Disulfide Bond Partners Using Ultraviolet Photodissociation Mass Spectrometry. Anal Chem 83 (17):6455-6458

26. Devakumar A, Thompson MS, Reilly JP (2005) dFragmentation of oligosaccharide ions with $157 \mathrm{~nm}$ vacuum ultraviolet light. Rapid Commun Mass Spectrom 19 (16):2313-2320

27. Enjalbert Q, Racaud A, Lemoine J, Redon S, Ayhan MM, Andraud C, Chambert S, Bretonniere Y, Loison C, Antoine R, Dugourd P (2011) Optical Properties of a Visible PushPull Chromophore Covalently Bound to Carbohydrates: Solution and Gas-Phase Spectroscopy Combined to Theoretical Investigations. J Phys Chem B 116 (2):841-851

28. Racaud A, Antoine R, Joly L, Mesplet N, Dugourd P, Lemoine J (2009) WavelengthTunable Ultraviolet Photodissociation (UVPD) of Heparin-Derived Disaccharides in a Linear Ion Trap. J Am Soc Mass Spectrom 20 (9):1645-1651

29. Gabelica V, Rosu F, De Pauw E, Antoine R, Tabarin T, Broyer M, Dugourd P (2007) Electron photodetachment dissociation of DNA anions with covalently or noncovalently bound chromophores. J Am Soc Mass Spectrom 18 (11):1990-2000

30. Gabelica V, Tabarin T, Antoine R, Rosu F, Compagnon I, Broyer M, De Pauw E, Dugourd P (2006) Electron photodetachment dissociation of DNA polyanions in a quadrupole ion trap mass spectrometer. Anal Chem 78 (18):6564-6572

31. Smith SI, Brodbelt JS (2011) Hybrid Activation Methods for Elucidating Nucleic Acid Modifications. Anal Chem 83 (1):303-310

32. Balbeur D, Dehareng D, De Pauw E (2010) Identification of Fragmentation Channels of Dinucleotides Using Deuterium Labeling. J Am Soc Mass Spectrom 21 (1):23-33

33. Gabelica V, Rosu F, De Pauw E, Lemaire J, Gillet JC, Poully JC, Lecomte F, Gregoire G, Schermann JP, Desfrancois C (2008) Infrared signature of DNA G-quadruplexes in the gas phase. J Am Chem Soc 130 (6):1810-+

34. Hao C, Le Blanc JCY, Verkerk UH, Siu KWM, Loboda AV (2010) Ultraviolet photodissociation of protonated pharmaceuticals in a pressurized linear quadrupole ion trap. Rapid Commun Mass Spectrom 24 (15):2262-2268 
35. Wilson JJ, Brodbelt JS (2007) MS/MS simplification by $355 \mathrm{~nm}$ ultraviolet photodissociation of chromophore-derivatized peptides in 4-3 quadrupole ion trap. Anal Chem 79 (20):7883-7892

36. Diedrich JK, Julian RR (2010) Site-Selective Fragmentation of Peptides and Proteins at Quinone-Modified Cysteine Residues Investigated by ESI-MS. Anal Chem 82 (10):40064014

37. Enjalbert Q, Simon R, Salvador A, Antoine R, Redon S, Ayhan MM, Darbour F, Chambert S, Bretonniere Y, Dugourd P, Lemoine J (2011) Photo-SRM: laser-induced dissociation improves detection selectivity of selected reaction monitoring mode. Rapid Commun Mass Spectrom 25 (22):3375-3381

38. Crowe MC, Brodbelt JS (2005) Differentiation of phosphorylated and unphosphorylated peptides by high-performance liquid chromatography-electrospray ionization-infrared multiphoton dissociation in a quadrupole ion trap. Anal Chem 77 (17):5726-5734

39. Madsen JA, Cullen TW, Trent MS, Brodbelt JS (2011) IR and UV Photodissociation as Analytical Tools for Characterizing Lipid A Structures. Anal Chem 83 (13):5107-5113

40. Hortin GL, Sviridov D, Anderson NL (2008) High-abundance polypeptides of the human plasma proteome comprising the top $4 \operatorname{logs}$ of polypeptide abundance. Clin Chem 54 (10):1608-1616

41. MacLean B, Tomazela DM, Abbatiello SE, Zhang SC, Whiteaker JR, Paulovich AG, Carr SA, MacCoss MJ (2010) Effect of Collision Energy Optimization on the Measurement of Peptides by Selected Reaction Monitoring (SRM) Mass Spectrometry. Anal Chem 82 (24):10116-10124

42. MacLean B, Tomazela DM, Shulman N, Chambers M, Finney GL, Frewen B, Kern R, Tabb DL, Liebler DC, MacCoss MJ (2010) Skyline: an open source document editor for creating and analyzing targeted proteomics experiments. Bioinformatics 26 (7):966-968

43. Kuzyk MA, Smith D, Yang J, Cross TJ, Jackson AM, Hardie DB, Anderson NL, Borchers CH (2009) Multiple Reaction Monitoring-based, Multiplexed, Absolute Quantitation of 45 Proteins in Human Plasma. Mol Cell Proteomics 8 (8):1860-1877

44. Addona TA, Abbatiello SE, Schilling B, Skates SJ, Mani DR, Bunk DM, Spiegelman CH, Zimmerman LJ, Ham A-JL, Keshishian H, Hall SC, Allen S, Blackman RK, Borchers CH, Buck C, Cardasis HL, Cusack MP, Dodder NG, Gibson BW, Held JM, Hiltke T, Jackson A, Johansen EB, Kinsinger CR, Li J, Mesri M, Neubert TA, Niles RK, Pulsipher TC, Ransohoff D, Rodriguez H, Rudnick PA, Smith D, Tabb DL, Tegeler TJ, Variyath AM, Vega-Montoto LJ, Wahlander A, Waldemarson S, Wang M, Whiteaker JR, Zhao L, Anderson NL, Fisher SJ, Liebler DC, Paulovich AG, Regnier FE, Tempst P, Carr SA (2009) Multi-site assessment of the precision and reproducibility of multiple reaction monitoring-based measurements of proteins in plasma. Nat Biotechnol 27 (7):633-U685

45. Keshishian H, Addona T, Burgess M, Mani DR, Shi X, Kuhn E, Sabatine MS, Gerszten RE, Carr SA (2009) Quantification of Cardiovascular Biomarkers in Patient Plasma by Targeted Mass Spectrometry and Stable Isotope Dilution. Mol Cell Proteomics 8 (10):23392349

46. Paulovich AG, Billheimer D, Ham A-JL, Vega-Montoto L, Rudnick PA, Tabb DL, Wang P, Blackman RK, Bunk DM, Cardasis HL, Clauser KR, Kinsinger CR, Schilling B, Tegeler TJ, Variyath AM, Wang M, Whiteaker JR, Zimmerman LJ, Fenyo D, Carr SA, Fisher SJ, Gibson BW, Mesri M, Neubert TA, Regnier FE, Rodriguez H, Spiegelman C, Stein SE, Tempst P, Liebler DC (2010) Interlaboratory Study Characterizing a Yeast Performance Standard for Benchmarking LC-MS Platform Performance. Mol Cell Proteomics 9 (2):242254

47. Prakash A, Rezai T, Krastins B, Sarracino D, Athanas M, Russo P, Ross MM, Zhang H, Tian Y, Kulasingam V, Drabovich AP, Smith C, Batruch I, Liotta L, Petricoin E, Diamandis 
EP, Chan DW, Lopez MF (2010) Platform for Establishing Inter laboratory Reproducibility of Selected Reaction Monitoring-Based Mass Spectrometry Peptide Assays. J Proteome Res 9 (12):6678-6688 
Figure 1. LC-MS/MS chromatograms of 12 SRM transitions of cysteine-containing peptides from human serum tagged with DABCYL C2 maleimide. The photo-SRM experiment (a) shows a decrease of interferences ( $\mathbf{\nabla})$ compare to the SRM one (b). All * show the peaks corresponding to the target molecules.

Figure 2. a)-d) CID MS/MS spectra were used to confirm the sequence of the different peptides (afamin a), $\mathrm{C} 4 \mathrm{~b}$ binding protein alpha chain $\mathrm{b}$ ), complement $\mathrm{C} 3 \mathrm{c}$ ), gelsolin d)). All * show triply charged precursor ions of the target molecules, while the fragment ion in italic and bold are the ones followed in photo-SRM and SRM experiments (not visible for Fig. 2b) because this product ion is out of range). e)-h) LC-MS/MS chromatograms obtained by photo-SRM (black) and SRM (red) analysis of most intense specific transitions for four cysteinecontaining peptides from human serum tagged with DABCYL C2 maleimide (afamin $m / z$ 494/372 e), C4b binding protein alpha chain $m / z$ 732/1212 f), complement C3 m/z 344/443 g), gelsolin $m / z$ 552/784 h)). All show the peaks corresponding to the target molecules.

Figure 3. LC-MS/MS chromatograms of the most specific intense transition tracking a proteotypic peptide from the C4b binding protein Alpha chain $m / z$ 732/1212. Photo-SRM a) and SRM c) analyses of chromophorederivatized rat plasma ( $\mathrm{C} 4 \mathrm{~b}$ binding protein Alpha chain concentration $=0 \mu \mathrm{g} / \mathrm{mL})$. Photo-SRM b) and SRM d) analyses of chromophore-derivatized human serum spiked into rat plasma ( $\mathrm{C} 4 \mathrm{~b}$ binding protein Alpha chain concentration $=6.75 \mu \mathrm{g} / \mathrm{mL}$ ). e) Calibration curves of the most intense specific transition obtained following chromophore-derivatized proteotypic C4b binding protein Alpha chain peptide in photo-SRM (๘) and SRM ( $\mathbf{\Delta})$ modes. Inset shows low concentrations data $(0,6.75,33.75,67.5 \mu \mathrm{g} / \mathrm{mL})$. 


\begin{tabular}{|c|c|c|c|c|c|c|c|c|c|c|c|}
\hline Protein name & Peptide SRM & $\begin{array}{c}\text { Peptide photo- } \\
\text { SRM }\end{array}$ & \begin{tabular}{|c|}
$\begin{array}{c}\text { Collision } \\
\text { energy } \\
\text { (SRM/photo- } \\
\text { SRM) }\end{array}$ \\
\end{tabular} & Area in SRM & $\begin{array}{c}\text { Area in } \\
\text { photo-SRM }\end{array}$ & $\begin{array}{l}\text { Height in } \\
\text { SRM }\end{array}$ & $\begin{array}{c}\text { Height in } \\
\text { photo-SRM }\end{array}$ & $\begin{array}{c}\text { Retention } \\
\text { Time in SRM } \\
\text { (min) }\end{array}$ & $\begin{array}{c}\text { Retention } \\
\text { Time in } \\
\text { photo-SRM } \\
\text { (min) } \\
\end{array}$ & $\begin{array}{c}\text { Transition in } \\
\text { SRM }\end{array}$ & $\begin{array}{c}\text { Transition in } \\
\text { photo-SRM }\end{array}$ \\
\hline Afamin & DADPDTFFAK & ICAMEGLPQK & 24/5+LID & $1.80 \mathrm{E}+04$ & $1.16 \mathrm{E}+04$ & $1.08 \mathrm{E}+03$ & $1.10 \mathrm{E}+03$ & 7.44 & 25.04 & $564 / 825$ & $494 / 372$ \\
\hline Albumin & LVNEVTEFAK & CASLQK & 35/5+LID & $3.97 \mathrm{E}+07$ & $5.60 \mathrm{E}+06$ & $2.41 \mathrm{E}+06$ & $2.00 E+06$ & 5.94 & 17.26 & $575 / 937$ & $347 / 475$ \\
\hline $\begin{array}{c}\text { C4b Binding Protein } \\
\text { Alpha Chain }\end{array}$ & GYILVGQAK & YTCLPGYVR & 29/5+LID & $1.39 \mathrm{E}+05$ & $2.60 E+05$ & $1.05 \mathrm{E}+04$ & $1.20 E+04$ & 5.03 & 26.4 & $629 / 1015$ & $732 / 1212$ \\
\hline Complement C3 & TGLQEVEVK & FSCQR & $25 / 5+$ LID & $2.63 E+05$ & $1.60 E+06$ & $2.42 E+04$ & $1.20 E+05$ & 4.69 & 18.38 & $502 / 731$ & $344 / 443$ \\
\hline Gelsolin. isoform 1 & TGAQELLR & SEDCFILDHGK & $25 / 5+$ LID & $6.51 \mathrm{E}+04$ & $2.50 \mathrm{E}+04$ & $5.12 \mathrm{E}+03$ & $1.60 \mathrm{E}+03$ & 4.7 & 27.6 & $444 / 530$ & $552 / 784$ \\
\hline Haptoglobin beta chain & VGYVSGWGR & VMPICLPSK & $25 / 5+$ LID & $1.38 \mathrm{E}+06$ & $2.20 E+06$ & $1.01 \mathrm{E}+05$ & $1.1 E+05$ & 5.48 & 28.68 & $491 / 562$ & $460 / 575$ \\
\hline Plasminogen & LFLEPTR & QLGAGSIEECAAK & $18 / 5+$ LID & $5.78 \mathrm{E}+05$ & $3.50 E+05$ & $4.00 E+04$ & $2.50 E+04$ & 5.86 & 24.05 & $438 / 615$ & $557 / 242$ \\
\hline
\end{tabular}

Table 1. Data for proteotypic peptides analyzed by common SRM and photo-SRM experiments. Values show in bold are the ones better in photo-SRM than in SRM.

\begin{tabular}{|c|c|c|c|c|c|c|c|c|}
\hline \multicolumn{4}{|c|}{ Afamin } & \multicolumn{4}{c|}{ Albumin } & \multicolumn{3}{c|}{ C4b binding protein alpha chain } \\
\hline$\mu \mathrm{g} / \mathrm{mL}$ & Accuracies & $\mathrm{CV}(\mathrm{n}=3)$ & $\mu \mathrm{g} / \mathrm{mL}$ & Accuracies & $\mathrm{CV}(\mathrm{n}=3)$ & $\mu \mathrm{g} / \mathrm{mL}$ & Accuracies & $\mathrm{CV}(\mathrm{n}=3)$ \\
\hline 0 & NA & NA & 0 & NA & NA & 0 & NA & NA \\
\hline 1.13 & NA & NA & 410 & 107 & 21 & 3.38 & NA & NA \\
\hline 2.25 & NA & NA & 820 & 118 & 6 & 6.75 & 82.1 & 17 \\
\hline 11.25 & NA & NA & 4100 & 109 & 6 & 33.75 & 95 & 19 \\
\hline 22.5 & 104 & 16 & 8200 & 112 & 5 & 67.5 & 113 & 9 \\
\hline 56.25 & 89 & 13 & 20500 & 101 & 4 & 168.75 & 101 & 14 \\
\hline 112.5 & 102 & 10 & 41000 & 96 & 12 & 337.5 & 105 & 16 \\
\hline \multicolumn{2}{|c|}{ Complement C3 } & \multicolumn{1}{|c|}{ Gelsolin } & & & Plasminogen & \\
\hline$\mu \mathrm{g} / \mathrm{mL}$ & Accuracies & CV ( $\mathrm{n}=3)$ & $\mu \mathrm{g} / \mathrm{mL}$ & Accuracies & $\mathrm{CV}(\mathrm{n}=3)$ & $\mu \mathrm{g} / \mathrm{mL}$ & Accuracies & $\mathrm{CV}(\mathrm{n}=3)$ \\
\hline 0 & NA & NA & 0 & NA & NA & 0 & NA & NA \\
\hline 8.25 & 104 & 9 & 32 & NA & NA & 2.7 & NA & NA \\
\hline 16.5 & 94.5 & 18 & 6.4 & NA & NA & 13.5 & NA & NA \\
\hline 82.5 & 90.4 & 14 & 32 & NA & NA & 27 & 109 & 8 \\
\hline 165 & 88.1 & 10 & 64 & 102 & 15 & 54 & 85 & 21 \\
\hline 412.5 & 110 & 4 & 160 & 99 & 10 & 135 & 107 & 6 \\
\hline 825 & 113 & 13 & 320 & 100 & 20 & 270 & 98.4 & 15 \\
\hline
\end{tabular}

Table 2. Analytical performance levels by photo-SRM (precision and accuracy) calculated for replicated calibration curves of cystein-containing peptides tagged with a dansyl chromophore tracking six proteins of human serum diluted into rat plasma. Accuracies are expressed as percent difference: ((concentration found concentration added) /concentration added) X 100 . 
a)

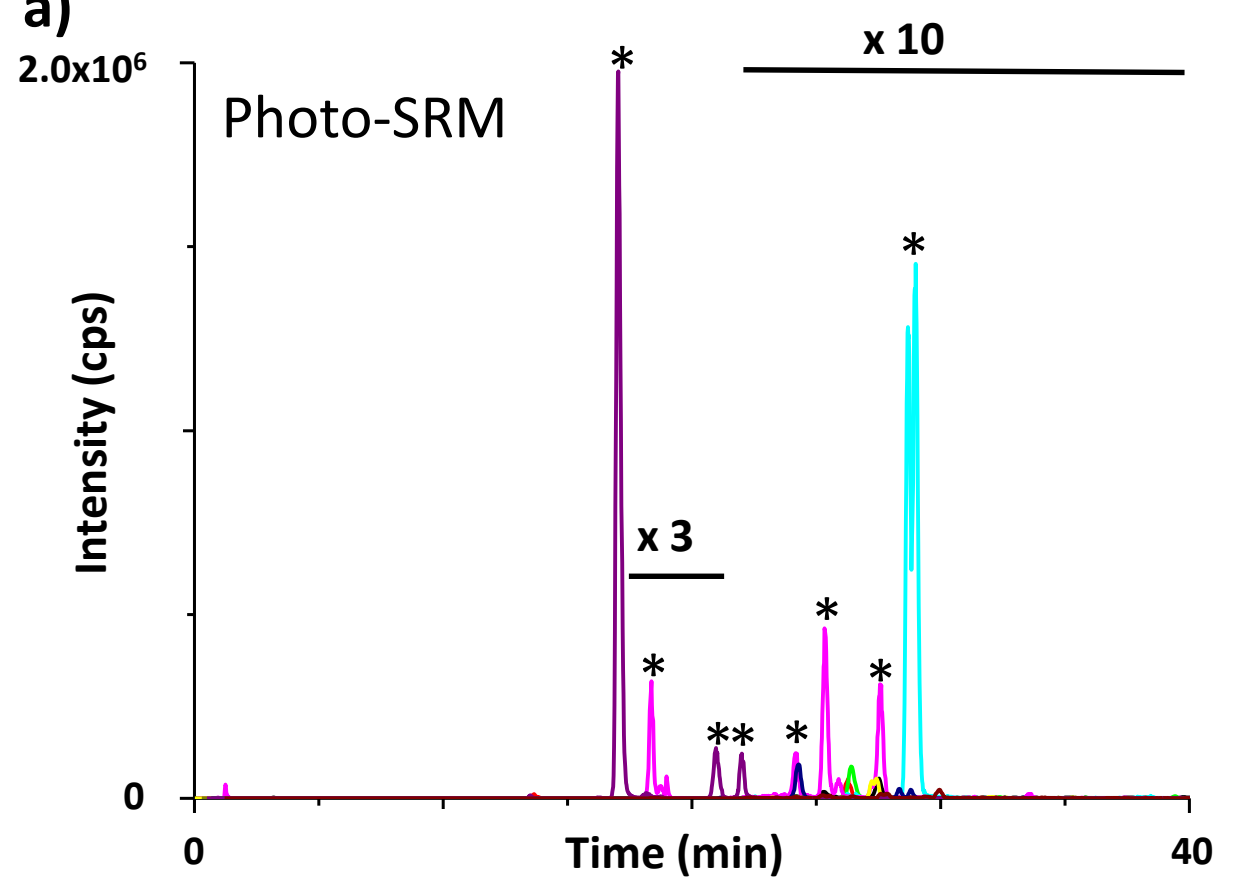

b)

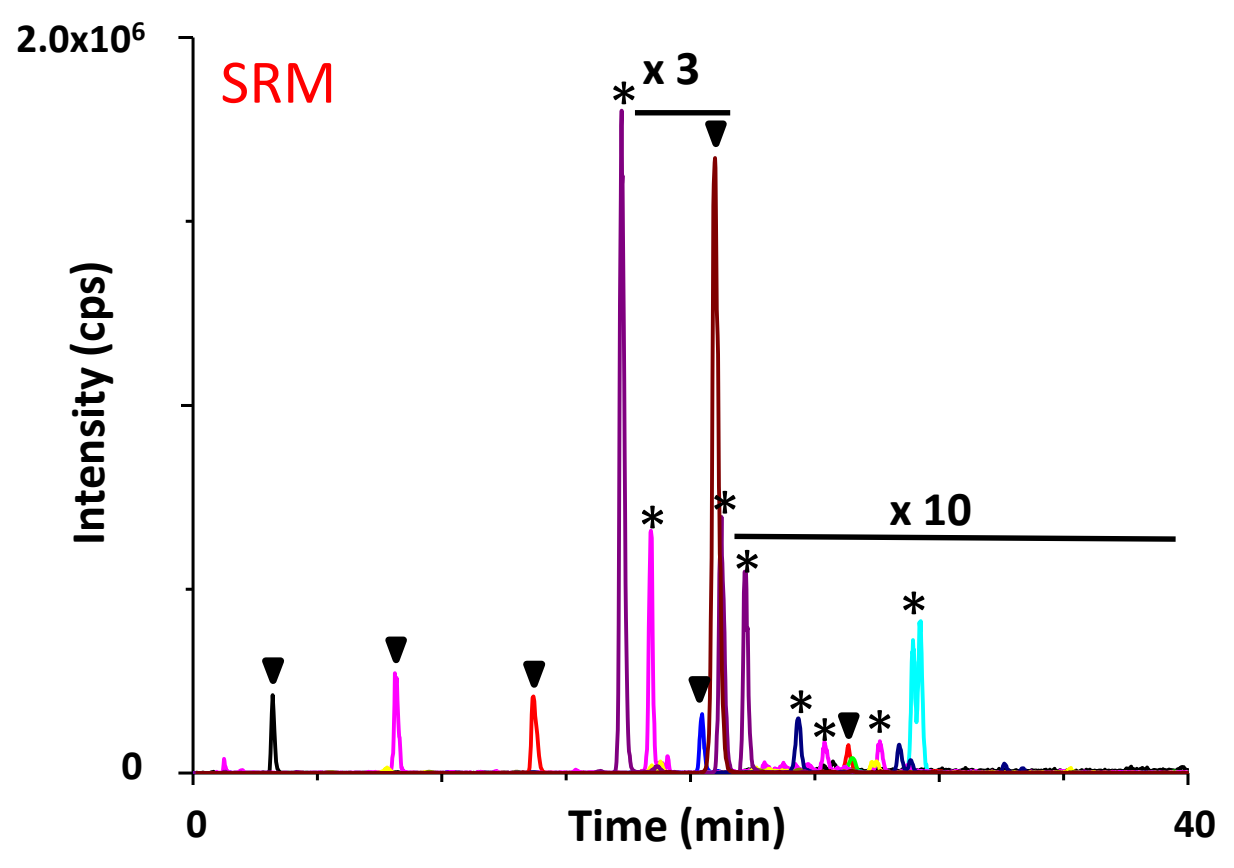

Figure 1. 

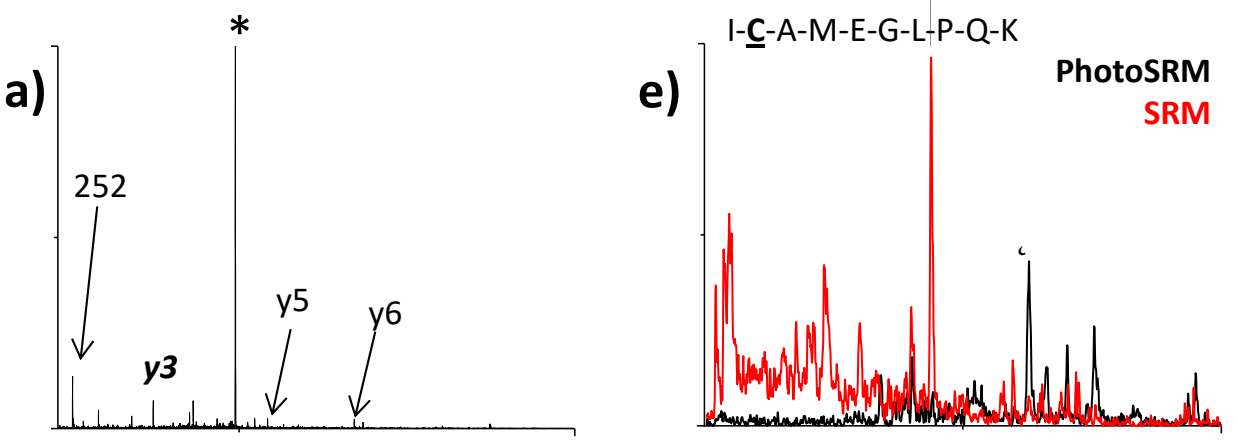

C4b binding protein alpha cha...
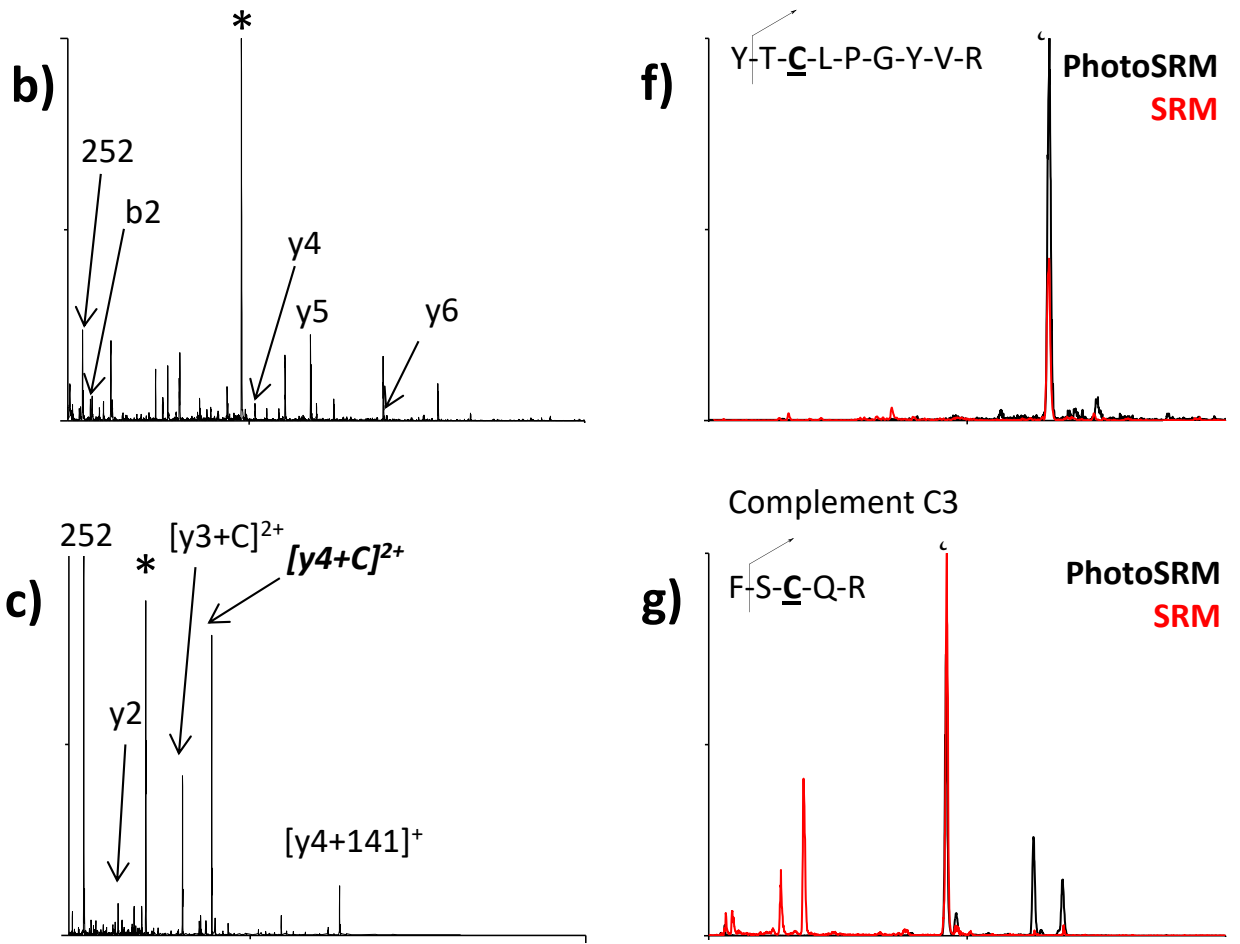

Complement C3

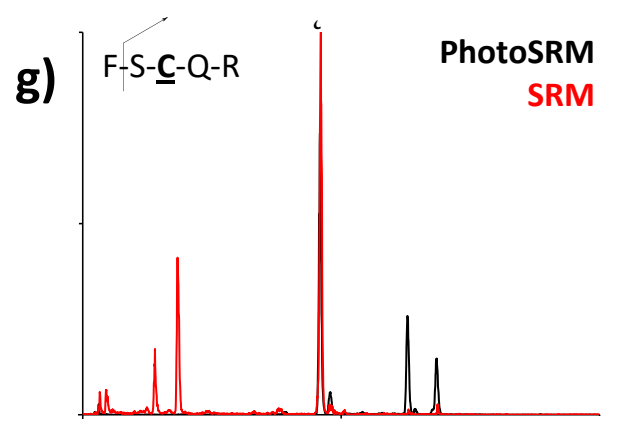

Gelsolin isoform 1
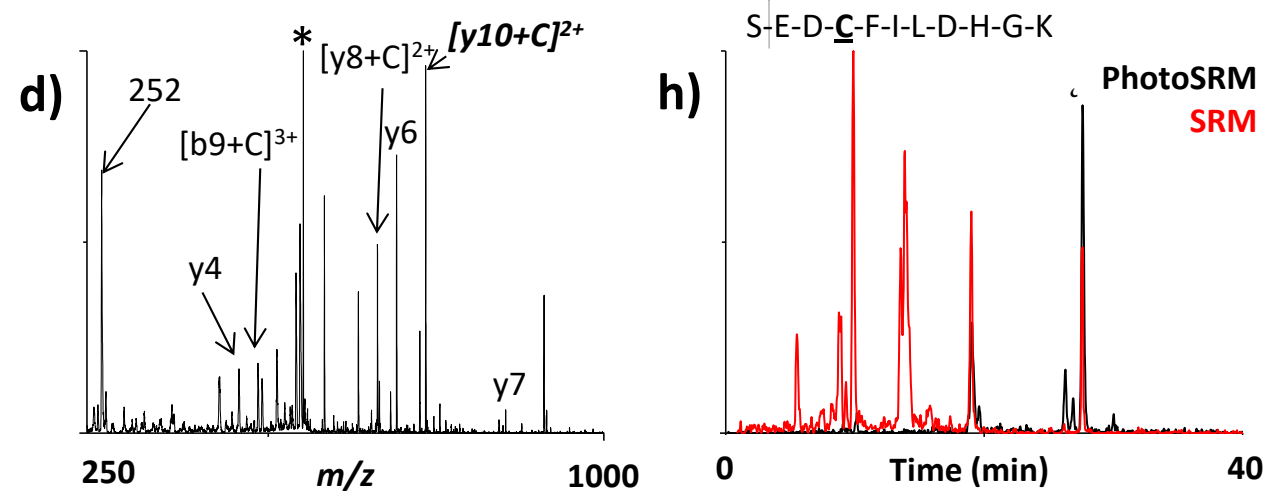

Figure 2. 
a)

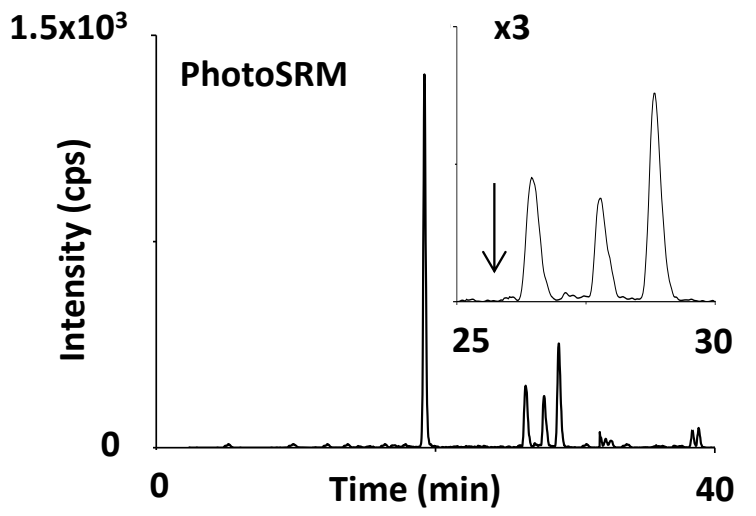

b)

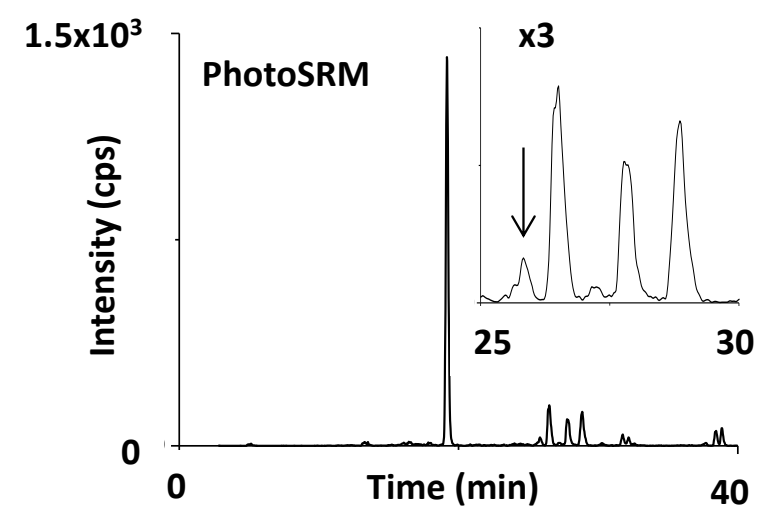

e)

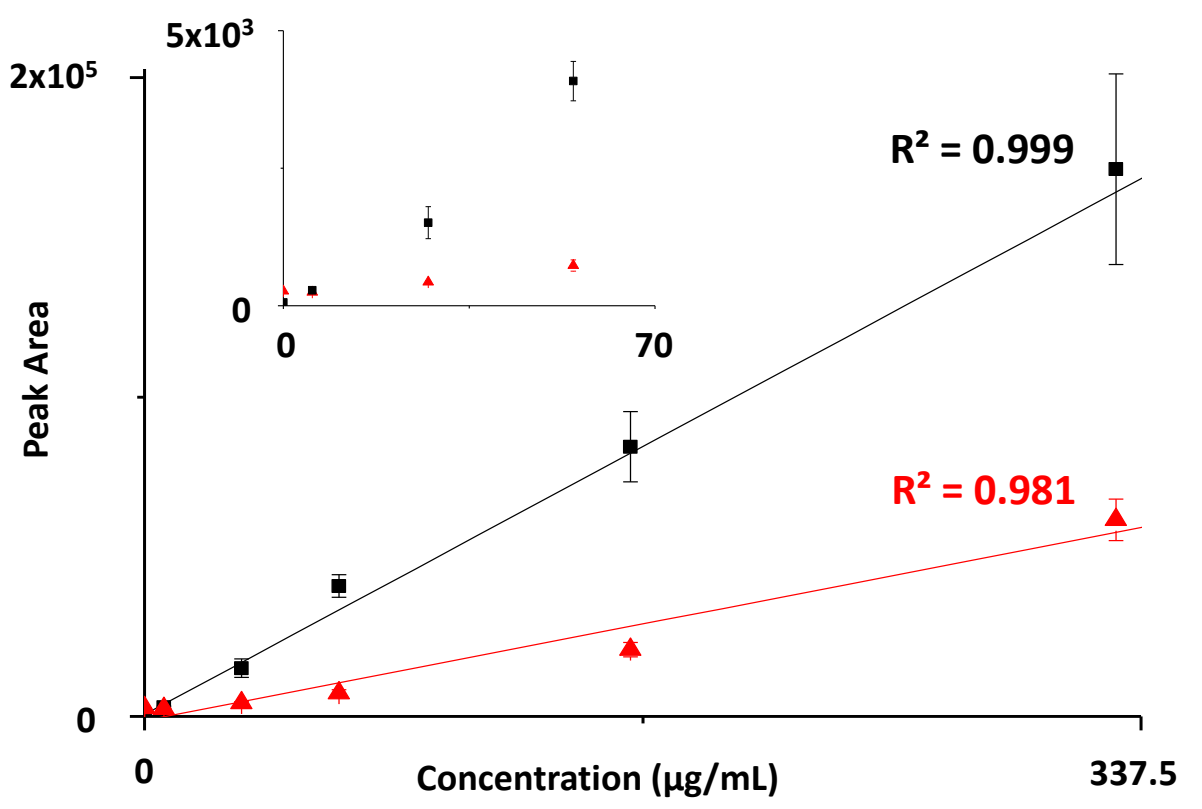

c)

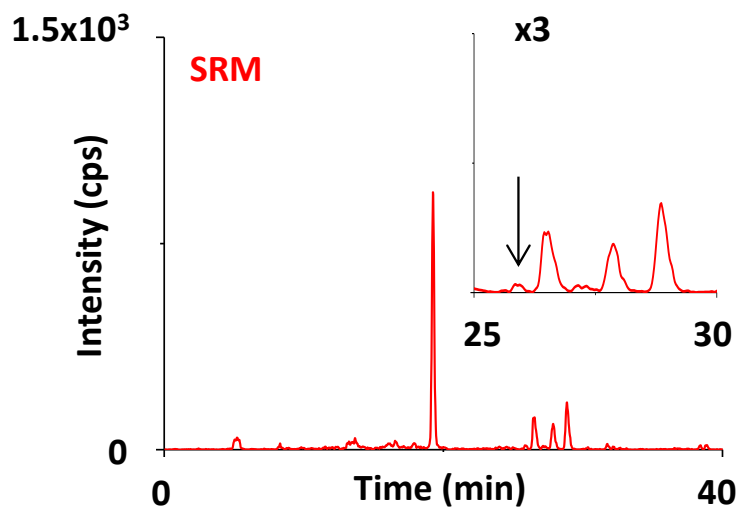

d)

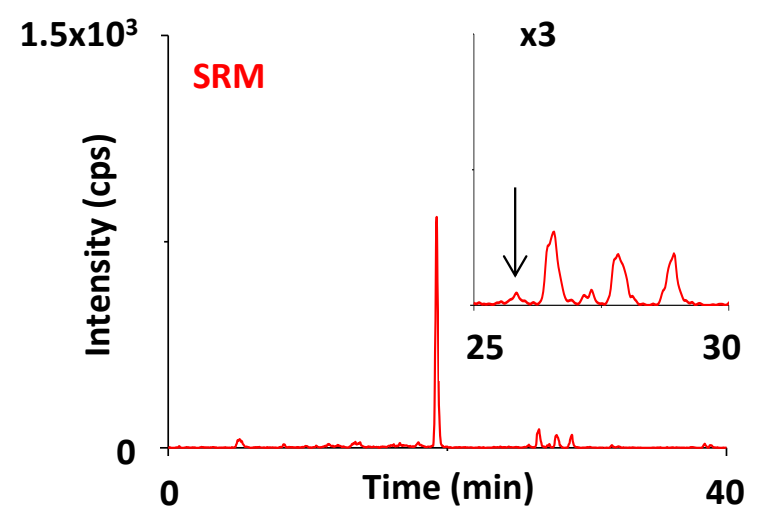

Figure 3. 